\title{
Industry-University Interactions in a Peripheral European Region: An Empirical Study of Valencian Firms
}

\section{Adela García-Aracil}

\section{Ignacio Fernández de Lucio}

Institute for Innovation and Knowledge Management, INGENIO (CSIC-UPV)*

Universidad Politécnica de Valencia, Camino de Vera, s/n, 46022 Valencia (Spain)

Telf: +3496387 7048. Fax: +3496387 7991 .

e-mail: agarcia@ingenio.upv.es; ifernand@ingenio.upv.es

\footnotetext{
*We thank to the Valencian government "Alto Consejo Consultivo de la Generalitat

Valenciana" for its support on carrying out the survey "Encuesta a la Comunidad Empresarial

Valenciana sobre las relaciones universidad-empresa" used in this paper.
} 


\title{
Industry-University Interactions in a Peripheral European Region: An Empirical Study of Valencian Firms
}

\begin{abstract}
In this paper we analyse the interactions among industry and academic staff in the Mediterranean Spanish Region of Valencia. The information comes from the manufacturing firm survey about I-U collaboration carried out in 2001 by the Valencian administration. Our findings show that the factors that had the most influence on I-U interaction are those related to firms' structural characteristics, in particular managers' qualifications and the sector of activity. Firm size was less of an influence. Firms prefer interactions related to the training of students and education of personnel rather than performance of contract $R \& D$ and joint $R \& D$ projects.
\end{abstract}

Keywords: Industry-University interactions; managers' educational level.

JEL: Technological Change, Research and Development; Econometric Methods.

\section{Introduction}

Intense global competition, rapid technological change and shorter product life cycles have transformed the current competitive environment (Ali, 1994; Keeble, 1997; Prahalad, 1998; Kitson et al., 2004). Consequently, there are increased pressures on firms to continually advance their knowledge and technologies to ensure long-term prosperity and survival (Steele, 1989; Ali, 1994; Polenske, 2004). Because it is becoming increasingly more difficult for firms 
to rely exclusively on in-house activities due to limited expertise and resources (Pisano 1990; Hamel and Prahalad, 1994), firms have to acquire knowledge and technology from a variety of external sources.

The interactive nature of the innovation process makes it necessary for firms to cooperate with other organisations to conduct through their research and development (R\&D) initiatives. These include competing firms, research organisations, government laboratories, industry research associations, and universities (Kleinknecht and Reijen, 1992; Hakanson, 1993; Hameri, 1996; Mora, 1999; Angel, 2002; García-Aracil et al., 2003). Universities are unique in terms of their potential. They are not only a source of knowledge and technology, they provide graduates and faculty that can become employees and consultants (Bonaccorsi and Piccaluga, 1994; Mansfield and Lee, 1996). While much of the inter-organisational literature focuses on collaboration between two or more industrial firms, we concentrate on collaboration between industrial firms and universities. Industry-university (I-U) alliances represent an evolving trend for the advancement of knowledge and new technologies (Cyert and Goodman, 1997; Cohen et al., 1998; Okubo and Sjoberg, 2000).

I-U relationships have a long history (Bower, 1993). Collaboration between industries and universities has emerged as one of the priorities in the OECD countries (OECD, 1998) and has become a trend in European innovation policy (European Commission, 2000). Relationships of this type have long been considered crucial to the development of the innovation system in any country (Lundvall, 1988; OECD, 1997; Patel and Pavitt, 1998). Furthermore, analysis of I-U relationships at regional level has received growing attention in the last few years (Varga, 1998, 2000; Isaksen and Hauge, 2002). The literature on regional innovation systems provides substantial descriptions and analyses of the relationship between innovation, learning and the economic performance of particular regions (Cooke 2001; Edquist, 2004). Many academics are pointing to the importance of the regional scale and of regional specific resources in 
stimulating the innovation capability and competitiveness of firms (Asheim et al., 2003; Cooke, 2003; Wolfe, 2003; Isaksen, 2002; Malmberg and Maskell, 2002). Maskell and Malmberg (1999) argue that firm-specific competencies and learning processes can lead to regional competitive advantage if they are based on localized capabilities such as specialized resources, skills, institutions and common social and cultural values. Overall, there continue to be compelling reasons for industrial firms and universities to work together (Santoro and Chakrabarti, 1999).

Relationships between industry and university have become more diversified and vary from academic research funded by industry, to I-U alliances and other forms of $R \& D$ partnering (Ahn, 1995). Although the university sector has for long been considered as a distinct organisation in society (Scott, 1995), and in spite of the development of a selfregulation system based on the establishment of funding agencies, controlled by the researchers themselves, a new type of collaboration between the three spheres (researchers, industries and government) has emerged - the triple helix. The role of universities has evolved from providing industry and the public sector with trained personnel, and transferring knowledge in the form of research results for industry to draw upon (Mansfield, 1991), to becoming a structural factor in the science-based innovation process (Leydesdorff and Etzkowitz, 2001) and encouraging industry-university collaboration. Universities provide their students and faculties with practical problems related to technological areas, and create employment opportunities for their graduates (NSB, 2000). Universities also interact with industry to access additional funds, particularly for research (Rosner, 1968; NSB, 2000). The role of government has developed from one of passive-assistance to a more active one involving stimulating the creation of linkages and facilitating the transfer of university innovations through incubator facilities and entrepreneurship centres (Klofsten et al., 1999). 
According to Leydesdorff and Etzkowitz (2001), universities should become agencies of economic and social development, building on their main missions of teaching and research.

On the industry side, the objectives of firms' collaboration with researchers include research synergies, keeping abreast of major technological developments, and $\mathrm{R} \& \mathrm{D}$ cost sharing. The benefits to firms include access to highly trained students, facilities, and faculty, and the enhanced image derived from collaboration with a prominent academic institution.

In a context where the dependency between university, industry and government is growing, firms are becoming an important participant in national knowledge production. As markets become segmented, demanding more technologically sophisticated solutions, firms are being required to become more directly involved in knowledge production. As a result of the complementary nature of I-U relationships, some of these collaborative activities have been instrumental in helping firms advance in knowledge and new technologies in many areas, e.g., biotechnology (Pisano, 1990), pharmaceuticals (van Rossum and Cabo, 1995) and manufacturing (Frye, 1993).

The channels used for transferring knowledge and technology depend on their characteristics, such as the degree of codification of the knowledge, and the tacitness or the embeddedness of the technology. The potential economic value of knowledge also affects the way that knowledge is exchanged between the actors, sometimes requiring interactions that ensure secrecy, increase trust and allow for exclusive appropriation of that knowledge (Saviotti, 1998). Certain I-U activities incorporate and demand specific technical knowledge from the technical cores of both organisations (Schartinger et al., 2002). For example, technology transfer occurs through a dense network of individual ties among university scientists and engineers, and industrial firm R\&D personnel (Oliver and Liebeskind, 1998). Much research in organisation theory shows that an organisation's structure is closely linked to firm size and plays a role in a firm's ability to adapt to the environment, create and 
assimilate knowledge, and be innovative (Burns and Stalker, 1961, Torre and Rallet, 2005; Boschma, 2005). Organisational structure is also a factor that directly impacts on the dynamic capabilities of the firm (Teece et al., 1997). As such, an organisation's structure affects both knowledge and technology transfer. Moreover, knowledge and/or technology transfer involve identification of appropriate sources, interaction with those sources, acquisition of the knowledge and/or technology, and their integration organisational systems and procedures (Zmud, 1982). Thus, a factor critical to the success of interactive activities is the firm's ability to accurately understand, interpret, evaluate, and absorb the specific knowledge and technologies (Cohen and Levinthal, 1990).

Cohen et al. (1998) examine the relative importance of a set of transfer channels from the perspective of the knowledge recipient, the firms. Agrawal and Henderson (2000) focus on the relative importance of the transfer channels from the perspective of the knowledge creator, the university teachers and researchers. All these studies deepen our understanding of tacit knowledge transfer and the relative abilities of firms to use university inventions effectively ("absorptive capacity") (Griffith et al., 2003). Similarly, the term "receptivity" is used to describe the overall ability of organisations to be aware of, to identify and to take effective advantage of new knowledge (Seaton and Cordey-Hayes, 1993). Connectedness is important because the knowledge associated with an invention is not completely transferred in the form of patents or publications, but rather requires some sort of interaction between the inventor and the recipient firm.

There is a growing literature on the characteristics of the firm that influence its ability to utilize externally generated scientific knowledge, such as that transferred from universities. This branch of research originates from two papers by Cohen and Levinthal (1989, 1990), which introduced the concept of absorptive capacity and argue that a firm's ability to apply university research for its own commercial gains is a function of its investment in R\&D. 
Cockburn and Henderson (1998) build on this notion, but add that the degree to which firms are connected to universities is also important for utilizing knowledge spillovers. Lim (2000) restructures the above concepts and argues that the absorptive capacity of firms is primarily a function of their connectedness, in which investment in $R \& D$ is just one of several components. Zucker et al. (2000) investigate the importance of firm connectedness by examining their location decisions relative to star university scientists. Shane and Stuart (2000) study university start-up firms and examine the importance of connectedness, in this case not with the scientific community, but rather with the venture capital community. Ziedmonis (1999) does not consider connectedness, but rather examines the firm's related knowledge assets and its ability to evaluate external technology in terms of its likelihood to take out a licence or an option on a technology.

In recent years, most studies on I-U interactions have been based on detailed analysis of: industry-science links in narrowly defined fields of research and technology (Ingham and Mothe, 1998; Fritsch and Lukas, 2001); the aggregate effect of university research on knowledge production in firms (Varga, 2000; Anselin et al., 1997); certain types of knowledge interactions such as citations of university research in firm patents (Jaffe et al., 1993; Santangelo, 2002); personnel mobility (Bania et al., 1992; Hicks, 2000); formal and informal personal interactions, co-operative education programmes, curriculum development, the recruitment of recent university graduates or the grants given by firms to students, personnel exchanges (Reams, 1986); joint publications (Hicks, 2000), I-U research consortia, trade associations, the co-authoring of research papers by university and industrial firm members (NSB, 2000); and formation of spin-offs by university members (Bower, 1993; OECD, 2000). Furthermore, I-U relations have been examined in the context of technology transfer with a strong focus on the use by and effects of the new technology coming from universities (i.e. patents, prototypes) for firms (Dodgson, 1992; Geisler, 1995; Rea et al., 1997; Bozeman, 
2000). All these studies are interesting examples of efforts to understand which interactive activities are more popular for addressing immediate industry problems.

From literature, it can be seen that there are many factors that affect the firm's choice to collaborate or not with a university (Lee, 1996, 2000; Roessner et al., 1996). In this paper we assess the effects of; manager's level of education, technological linkages among different categories of firms, etc. on why firms in the region of Valencia collaborate with universities.

The paper is organized as follows: section 2 offers an overview of the regional context; section 3 describes the data set and basic descriptive statistics; section 4 presents the empirical results, and section 5 provides conclusions and implications for policy makers.

\section{Regional context}

The rise in the popularity of regional innovation systems has been driven in part by the increased intensity of international competition in a globalising economy, the apparent shortcomings of traditional regional development models and policies, and the emergence of successful clusters of firms and industries in many regions around the world (Enright, 2001; Cooke 2001).

For the establishment of effective regional innovation systems and in order to improve the technological performance of a region, it is crucial to be aware of the existing links between the agents that make up the system (OECD, 2001). Innovation and technological progress are the result of a series of complex relationships that exist between the agents in question private enterprises, universities and public research institutes - and the people within them. The knowledge flows among these actors through four channels: (i) interaction among enterprises; (ii) interaction among enterprises, universities and public research centres; (iii) diffusion of knowledge and technology to enterprises; and (iv) personnel mobility (OECD, 1997). The aim of this paper is to study the second channel - interaction among enterprises, universities and public research centres - in the region of Valencia. 
The autonomous region of Valencia, with a population of approximately 4.5 million inhabitants representing 10.5 percent of the Spanish population, is situated along the eastern Mediterranean coast of Spain (see Figure 1A in Appendix A). It has a broad autonomy in science and technology. However, in Spain there are 17 autonomous regions and, as a result of this regionalisation, the agents involved in innovation are answerable to 18 authorities, one central and 17 regional governments, with different political ideologies and uneven knowledge about what a science and technology policy should encompass.

Valencia is an active industrial and commercial area producing textiles, footwear, metal products, chemicals, automobiles, furniture, toys, and ceramic and coloured tiles. In the Spanish context, it is one of the country's main industrial centres, together with Madrid, Catalonia or the Basque Country regions (COTEC, 1999). In socioeconomic terms and in the context of the European Union (EU), it could be considered a peripheral region (OECD, 1997). In 2002, the participation of the Region of Valencia in the national economy was slightly below its demographic weight, in terms of GDP, it represented 9.7 per cent of the Spanish economy (INE, 2002).

The Valencian economy is based on small and medium-sized firm structures. 67.0 per cent of industrial companies have less than 6 employees, and 22.0 per cent between 6 and 19 employees (INE, 2002). Its participation in European and National research programmes is relatively poor, especially when compared to the regions of Madrid and Catalonia. The level of R\&D spending in the Valencian region is even lower than the already low Spanish level, 0.6 and 0.9 per cent of GNP, respectively (INE, 2002). This tendency is replicated in public and private expenditure levels (European Commission, 2000). The performance of Valencian firms in terms of regional R\&D expenditure is very low: in 2002 it was only 35.0 per cent, the majority in this region being down to universities. In 2002 university R\&D expenditure reached almost 54.0 per cent of total investment in $R \& D$ in the region. This is not the same as 
the pattern at national level, where 55.0 per cent of $R \& D$ expenditure is by firms, and 30.0 per cent by universities. This structural imbalance in the Valencian region is even more noticeable when compared to the OECD average (OECD 2004), where R\&D expenditure by firms was 62.0 per cent of the total in 2002, while expenditure by universities was 18.0 per cent. The profile of the region has a major influence on I-U collaboration, R\&D and innovation activities.

In this context, the Valencian government is trying to design and impose a science and technology policy that will raise the average level of public and private investment up to that of the most advanced regions in the rest of Spain and in Europe. Taking as reference the actions planned in the European and National Frameworks, the Valencian government has proposed through the PVIDI (the Valencian Scientific Research, Technological Development and Innovation Plan, Generalitat Valenciana, 2001) a number of actions to develop the regional potential, mitigate its deficiencies and establish suitable directions for the future. Focusing on the interactions between industrial partners and academic staff, and in the absence of a central register of information about these interactions, the Valencian administration in 2001 decided to carry out a survey, which we describe in the next section.

\section{Data set and basic descriptive statistics}

The data we use in this paper are taken from a representative and standardized mailed survey carried out in 2001 by the Valencian administration, in the peripheral Spanish region of Valencia -Encuesta a la Comunidad Empresarial Valenciana sobre las relaciones universidad-empresa (Survey in the Valencian region on industry-university collaboration). The sample selection was random and representative from 1,843 manufacturing firms, broken down into NACE code activity sectors 15 to 36, and 64.2 (telecommunications). Two prompts were administered in order to achieve more responses. Data were collected from 700 manufacturing firms, a response rate of about 38.0 per cent. 
The survey addressed I-U relationships, considering the different I-U linkages, the motives for collaboration, the variety of interactive activities, the barriers to collaboration (regulations and standards, lack of interest in university research, etc.), the agreements signed by firms and universities, and the role of the government in these commitments. The survey included questions about the general characteristics of the firm such as size, organisation structure, technological characteristics, as well as R\&D innovation activities in relation to new products or cost reductions, in order to determine to what extent these factors might explain varying R\&D performance and firm's different collaboration paths.

Table 1 shows the percentage of firms in our sample by activity sectors. We use Pavitt's (1984) taxonomy and theory about technological linkages among different categories of firms to take account of the activity sector to which the firm belongs. This enables firms to be aggregated into five different groups: supplier-dominated firms (mainly from the traditional sectors of manufacturing), large-scale firms (related to those producing standard materials or durable consumer goods and vehicles), specialist suppliers (those firms that are technologically relatively specialised, e.g. mechanical engineering), science-based firms (those in the chemical and electronic/electrical sectors) and information-intensive firms (e.g. telecommunications). We can see that the highest percentage is supplier-dominated firms (51.6 per cent). Specialist suppliers account for the next largest group of 21.7 per cent. Largescale firms come next with 15.0 per cent and science-based firms with 9.3 per cent. In contrast, the proportion of informative-intensive firms is relatively low, 2.4 per cent. Overall, the Valencian economy is based on traditional industrial sectors, which are characterised by a high proportion of labour-intensive sub-sectors and very small number of companies in the high technology and knowledge-intensive sectors.

(Table 1 here) 
Table 2 presents the percentage of firms in our sample by size. This variable is measured by the number of employees within the firm. Micro firms are those with 10 employees or less; small firms are those with 11 to 50 employees; medium from 51 to 250 employees; and large firms those with more than 250 employees. Table 2 shows that 70.4 per cent of Valencian firms are small. Medium firms account for the next largest group (18.0 per cent).

(Table 2 here)

Bearing in mind the influence of firm characteristics on the firm's propensity to engage in innovation activities, Table 3 compares the proportion of innovation activities in Valencian firms and Spain as a whole (INE, 2002). We can see that Valencia has a relatively small percentage of firms engaged in innovation activities compared to the national average, 29.6 and 35.3 per cent, respectively. According to international comparisons from CIS3 (Third Community Innovation Survey), both these percentages are lower than the 41.0 per cent reported as the EU average for the period 1998-2000 (Lucking, 2004).

(Table 3 here)

Table 3 also shows that there is a high proportion of innovative firms in the ceramic sector, an important manufacturing sector in the Valencian economy (47.4 per cent), only outranked by science-based firms (63.1 per cent). In contrast, those firms classified as specialist suppliers are the least innovative (21.7 per cent), which is even lower than those firms classified as supplier-dominated firms (24.1 per cent). This last feature could be affecting the growth and wealth of the Valencian region.

If the emphasis of the PVIDI is on the public innovation system, and if firms do not innovate of their own accord, it would seem reasonable to set up partnerships between businesses and public institutions in order to achieve at least some transfer of technology, some exchange of knowledge between organisations, and the initiation of joint innovation projects. This seems to be the view shared by the European Commission and the governments 
of Spain and Valencia, given that one of the priorities in their recent innovation policy is to intensify cooperation between the public and private sectors (European Commission, 2001). Here again, in this area Valencia and Spain fail to reach the European average. Table 4 shows that 11.0 per cent of innovative Valencian firms cooperate in innovation activities with universities, the percentage for Spanish firms is around 10.0 per cent, but the EU average stands at approximately 19.0 per cent (Lucking, 2004).

\section{(Table 4 here)}

Table 4 also shows the proportion of Valencian firms performing R\&D activities $(22.7$ per cent) and the proportion of those that collaborate in R\&D activities ( 6.6 per cent). Only around 20.0 per cent of those firms classified as science-based, large-scale and information-intensive cooperate with universities. However, the level of cooperation is even lower among firms classified as supplier-dominated and specialist suppliers. The pattern is similar for R\&D activities. On the other hand, there is a positive relationship between firm size and I-U collaboration, $R \& D$ activities and collaborative arrangements for $R \& D$ activities, i.e. the large the firm, the more likely it will become involved in I-U collaboration.

The survey asked about the ranking of a variety of reasons for collaborating with universities, from 0 (not at all important) to 3 (most important). Table 5 shows that the level of importance was quite similar for all motives. This result is not surprising if we take into account that Valencian firms do not typically use university relationships to provide solutions to critical issues affecting central business areas and core technologies. Nevertheless, if we consider that in the majority of cooperative partnerships, one of the crucial features is the motivation to learn from one's partner, thus acquiring knowledge that in the majority of cases will complement one's own (Gonard, 1999) this result is somewhat worrying. According to the theory of absorptive capacity (Cohen and Levinthal, 1990), in order to be able to absorb the scientific knowledge transferred by universities, firms need to have a strong internal R\&D 
capacity (Fundación Cotec, 1999), but it has also been shown that partnerships with universities cannot replace internal investment in basic R\&D (Bonaccorsi and Piccaluga, 1994; Acosta and Modrego, 1998; Ham and Mowery, 1998).

\section{(Table 5 here)}

Bearing in mind the importance of firm capabilities, and in particular how managers coordinate and integrate activities within the firm to make best use of the knowledge and technology, information about the managers' level of education is important. This was gathered from a ranking from 1 (primary level) to 5 (higher education degree). Different kinds of managers according to their position in the firm were ranked: managing directors, product managers, R\&D managers, administrative managers, and other chief executives. Table 6 shows that there is a positive relationship between the level of education of managers and I-U collaboration and R\&D activities. The better educated are the managers, the more likely the firm will engage in I-U collaboration and in R\&D activities.

\section{(Table 6 here)}

The survey also asked for information on factors hindering firms' collaboration with universities, and ranked them from 0 (not at all important) to 3 (most important). Table 7 shows that the level of importance ascribed to all factors seen as hampering collaboration was quite similar (around 1.5 points).

\section{(Table 7 here)}

From these data, the Valencia economy is based on traditional industrial sectors, with no tradition of engaging in I-U collaboration or R\&D activities, and it seems that firm owners do not generally have a modern business education background. There may also be other factors that deter firms from engaging in collaboration with universities. To assess the influence of these variables on I-U interaction, we estimated an econometric model. Results are shown in the next section. 


\section{Empirical results}

Our dependent variable takes two values: 1 if the firms collaborate with universities, 0 otherwise. To reflect our discrete dependent variable, if the firm collaborates or not with universities, we applied a probit model and conducted maximum-likelihood estimation (Green, 1997). To clarify the effects of each explanatory variable on I-U interactions, we estimate four different specifications of the probit equation. The first specification uses only educational variables for managers based on their position in the firm - chief manager, product manager, R\&D manager, administrative manager and other chief executives - as regressors (Model I). The second specification includes firm characteristics - industrial sector according to technological linkages and firm size - as regressors (Model II). The third specification includes as regressors the motives for collaborating (Model III). The fourth specification takes hampering factors as the regressors (Model IV). The estimation results for all four specifications of I-U are presented in Table 8.

\section{(Table 8 here)}

In the first specification (Model I), we find that manager's level of education has a strong influence on the incidence of I-U collaboration. We assign dummy variables the value 1 , if managers have completed higher education and 0 if they have not. Our empirical results show that those firms with managers with higher education are more likely to engage in I-U collaborations. In every cooperative partnership, at least two parties are involved and their relationships are influenced by absorptive capacity and connectedness. "Absorptive capacity" as understood by Cohen and Levithal $(1989,1990)$, denotes the firm's ability to understand and utilize university research. Cockburn and Henderson (1998) introduce the term "connectedness" to reflect the extent to which firms increase their internal capacity through university contacts. Thus, building absorptive capacity within firms requires management experience with technology, management willingness to seek a competitive position based on 
technology and with the support of technologists, and the skills to perceive business goals in the application of technology (Bailetti and Callahan, 1992; Cyert and Goodman, 1997; Goodwin and Johnston, 1999; Fundación Cotec, 1999).

The second specification (Model II) shows, that as expected (OECD, 1997), those firms, classified as large-scale, science-based and information-intensive are more likely to engage in I-U collaboration. This finding is endorsed by the results of an empirical study on Spanish firms conducted by Bayona et al. (2002). However, specialist suppliers did not show the same probability of participating in I-U activities as their supplier-dominated-firm counterparts, the omitted reference category. This result demonstrates a weakness in the development of the Valencian economy. On the other hand, firm size is shown to be an important factor. Assuming that there is a given probability of cooperation per unit of economic activity, the results corroborate that large enterprises, which are characterized by a relatively large amount of economic activity, are more likely to cooperate than smaller firms and also are more likely to have a higher number of cooperative relationships (Nelson and Winter, 1982; González et al., 1999; Pagano and Schivardi, 2003). Again, managers' education has the strongest impact.

In the third specification (Model III), several motives for firms to collaborate with universities are added as regressors. Only perform joint $R \& D$ activities has a statistically significant impact. Busom, (1993) and Cassiman (1999) obtained similar results. Obtain innovative ideas, discern technology trend, staff training, change of technology management, register product innovations and register process innovations had no significant effects on I-U collaboration. Again, the managers' level of education, the activity sector and the size of the firm were relevant to a firm's decision to collaborate with a university.

When the factors hampering I-U interaction are included in the equation (Model IV), the results for most of the previous key variables did not change significantly, although there were some differences: the effect of R\&D manager's having higher education was more marked, the 
effect of science-based firms and the performance of joint $R \& D$ on $I-U$ collaboration increased, with obtaining results very slowly being the greatest deterrent to collaboration. This suggests that managing collaboration between firms and universities is difficult, and problems of implementation and management frequently hamper the realization of the other goals of such collaboration (OECD 2001a). Collaborative R\&D may accelerate the transfer of research results from public R\&D performers to industry, but it is not possible to say would always necessarily be the case. The sheer complexity of the management requirements for $R \& D$ collaborations, especially if they involve several firms and more than one university, may slow the transfer of technology and knowledge. In addition, the costs of such transfer, including maintenance by participating firms of parallel R\&D efforts in-house and/or the rotation of staff to an offsite R\&D facility, may be beyond the resources of smaller firms. There is no compelling evidence about such effects, but detailed study of this issue is in its early stages.

In light of the above results, and in order to have a better understanding of the heterogeneity of the I-U interactions in the region of Valencia, we next report some information about the channels of interactions.

The survey asked for information about the importance of a variety of interactions including formal agreements (contracts between industry and university researchers) and informal networks (such as meetings and conferences). As many authors note (Bonaccorsi and Piccaluga, 1994; Faulkner and Senker, 1995; Schartinger et al., 2001), interactions can be classified in relation to their resource deployment, time length, and formalization agreements. Building on this literature, the survey enquired about which of the following nine interaction activities were preferred, although most were interdependent: informal contacts, advice and technical support, training students, education of personnel, contract $R \& D$, joint $R \& D$ projects, patenting, personnel mobility and develop joint $R \& D$ centres. 
Table 9 shows that, according to the evaluation made by the sample in our survey, advisory and technical support is the most preferred interaction. The low technological level of the Valencian industries could be one explanation for this finding. Education of personnel and training students are the next important I-U interaction types, probably due to the low absorptive capacity that characterizes Valencian industries, which makes employers more interested in training.

Informal contacts did not score as high as expected. In collaborating with each other, industrial firms and the university expose themselves to a degree of uncertainty, since each loses a certain amount of control over a specific resource (McAllister, 1995). This is especially so with respect to industrial firms, where tight control over a particular resource is often the key to competitive advantage. Consequently, when collaborating organisations build trust, they reduce the uncertainty by developing confidence in the other party or in their partner's expected behaviour (Das and Teng, 1998) and also reduce the degree of hierarchy between them (Ingham and Mothe, 1998). Thus, some level of mistrust among actors could explain our finding.

Contract $R \& D$ did not rank highly. A further interesting result is that managers ranked collaborative research higher than contract research. An explanation could be that collaborative research implies a bi-directional exchange of knowledge, whereas contract research is basically a one-directional import of knowledge for firms. The low ranking given to personnel mobility supports the weak relationship between industries and universities.

\section{(Table 9 here)}

\section{Conclusions}

In this paper we analysed the interactions between industrial partners and academics in the Mediterranean Spanish region of Valencia. Our analysis was based on data from the Encuesta a la Comunidad Empresarial Valenciana sobre las relaciones universidad-empresa survey, carried out in 2001 by the Valencian administration. Over the last few years, a number of 
studies have focused on the I-U interactions and several evaluations of scientific and technological policies have been published. Our research suggests three additional relevant points of interest. First, it is based on data from a peripheral region with low absorptive capacity in the context of the EU; hence we can provide a reasonable estimate of the contribution of I-U collaboration activities at regional level. Second, this study focuses on the firms' point of view. Thirdly, and related to the quality of the data regarding collaboration of firms with universities, we employed a number of performance-related information such as reasons for collaborating with universities, factors discouraging collaboration, channels of interactions, activity sectors according to technological linkages, firm size, and managers' educational level. This comprehensive data set allows a better understanding of the heterogeneity of I-U interactions in a region with low-level absorptive capacity, such as the Region of Valencia.

We found that the factors that had the most influence on I-U interaction are those related to firms' structural characteristics, in particular managers' qualifications and the sector of activity. Firm size was less of an influence.

The use in recent years of external knowledge in the innovation process has increased in importance. In order to assimilate and utilize this knowledge in an effective way, research has shown that increasing the internal capability of the firm increases the ability to absorb external knowledge. The results obtained in this study confirm that this is true in the type of region we studied; one of the basics for I-U interaction is a specialized staff in the firm. Our hypothesis is that managers' qualifications are a necessary condition for the firm to have absorptive capacity and to be able to manage the knowledge assimilated within the firm.

As we expected, the level of I-U collaboration increases in firms in high technology sectors (science-based and information intensive firms), but we also found that the interaction between large-scale firms and universities was the most significant; meanwhile the I-U 
collaboration between firms classified as specialist suppliers and as supplier-dominated was not so significant. This is related to the industrial structure of the region which includes a very small number of specialist supplier firms, while the large-scale firms include the ceramic sector and they are leaders in ceramics exports and production in the Region of Valencia next to the Emilia-Romagna Region (Italy) and, if we take out Chinese production, in the world. Consequently, this relation between the Valencian industrial structure and I-U interaction shows that the results from other studies are not generalisable to all regions.

In addition, the structure of the Valencian firms was also found to affects I-U interaction. Medium and large firms do not collaborate with universities any more than micro and small firms; there are few large firms in the region and they do not belong to high tech sectors.

Although generally firms and universities in the Region of Valencia do not have close connections, our results show that the main motives for firms' interaction with universities is development of joint $\mathrm{R} \& \mathrm{D}$, and it is only the fact that results are slow to diffuse that they see as a constraint.

Based on our results, we can make some recommendations for innovation policy in regions with low levels of absorptive capacity. In these contexts, support should be given for improvements to human resources and the promotions of job placements in firms for higher education graduates are necessary for future success. Other changes that could be implemented that would improve I-U interaction would be the development of new sectors based on science, but this would be a difficult and slow process and require the contribution of higher education graduates. In regions such as Valencia, based on benchmarking against advanced European regions, universities should stress research and knowledge and technology transfer more than their traditional mission of teaching. According to our results, training in universities is the foundation for regional economic growth and it should be accompanied by greater employment of graduates in regional firms. Our study shows that firms prefer 
interactions related to the training of students and education of personnel rather than performance of contract $R \& D$ and joint $R \& D$ projects.

Policy makers should promote greater I-U interaction and pay more attention to the instruments and the channels of interaction. In the case of the actors involved, the emphasis should be on firms rather than universities. Our results show that regions with a low level of absorptive capacity, policies designed to alleviate the problems arising from the productive structure will be very important. Traditional policies for promoting innovation, such as those based on the funding of projects or fiscal bonus, will yield disappointing results. 


\section{References}

Acosta J. and Modrego A. (1998) La financiación pública de proyectos de I+D cooperativos en España: los proyectos concertados del Plan Nacional de I+D, Documento de Trabajo 97/98-08, Universidad de La Laguna, Spain.

Agrawal A. and Henderson R. (2000) Putting patents in context: exploring knowledge transfer from MIT, Mimeo, Massachusetts Institute of Technology, USA.

Ahn S. (1995) A new program in cooperative research between academia and industry in Korea, involving centers of excellence, Technovation, 15(4), 241-257.

Ali A. (1994) Pioneering versus incremental innovation: review and research propositions, Journal of Product Innovation Management, 11, 46-61.

Angel D.P. (2002) Inter-firm collaboration and technology development partnerships within US manufacturing industries, Regional Studies, 36(4), 333-344.

Anselin L., Varga A. and Acs Z. (1997) Local geographic spillovers between university research and high technology innovations, Journal of Urban Economics, 42, 422-448.

Asheim B.T., Isaksen A., Nauwelaers C. and Tödtling F. (eds) (2003) Regional Innovation Policy for Small-Medium Enterprises. Edward Elgar, Cheltenham.

Bailetti A.J. and Callahan J.R. (1992) Assessing the impact of university interactions on an R\&D organization, $R \& D$ Management, 22(2), 145-156.

Bania N., Calkins L. and Dalenberg R. (1992) The effects of regional science and technology policy on the geographic distribution of industrial R\&D laboratories, Journal of Regional Science, 32, 209-228.

Bayona C., García T. and Huerta E. (2002) Collaboration in R\&D with universities and research centres: an empirical study of Spanish firms, $R \& D$ Management, 32(4), 321-341.

Bonaccorsi A. and Piccaluga A. (1994) A theoretical framework for the evaluation of university-industry relationships, $R \& D$ Management, 24(3), 229-247. 
Boschma R.A. (2005) Proximity and innovation: A critical assessment, Regional Studies, 39(1), 61-74.

Bower D.J. (1993) Successful joint ventures in science parks. Long Range Planning, 26(6), 114-120.

Bozeman B. (2000) Technology transfer and public policy: a review of research and theory, Research Policy, 29, 627-655.

Burns T. and Stalker G.M. (1961) The Management of Innovation, Tavistock, London.

Busom I. (1993) Los proyectos de I+D de las empresas: un análisis empírico de algunas de sus características, Revista Española de Economía, Monográgico: Investigación y Desarrollo, $39-65$.

Cassiman B. (1999) Cooperación en investigación y desarrollo. Evidencia para la empresa manufacturera española, Papeles de Economía Española, 81, 143-154.

Cockburn I. and Henderson R. (1998) Absorptive capacity, coauthoring behavior, and the organization of research in drug discovery, Journal of Industrial Economics, XLVI(2), $157-182$.

Cohen W., Florida R., Randazzese L. and Walsh J. (1998) Industry and the academy: uneasy partners in the cause of technological advance, in Noll R. (Ed.), Challenges to Research Universities. The Brookings Institute Washington, DC, 171-200.

Cohen W. and Levinthal D. (1990) Absorptive capacity: a new perspective on learning and innovation, Administrative Science Quarterly, 35, 128-152.

Cohen W. and Levinthal D. (1989) Innovation and learning: the two faces of R\&D, The Economic Journal, 99, 569-596.

Cooke P. (2003) Integrating global knowledge flows for generative growth in Scotland: Life sciences as a knowledge economy exemplar, in Potter, J. (ed.), Inward Investment, 
Entrepreneurship and Knowledge Flows in Scotland - International Comparisons. OECD, Paris.

Cooke P. (2001) Sistemas de innovación regional: conceptos, análisis y tipología, in Olazaran, M., Gómez, M. (eds.), Sistemas Regionales de Innovación, Universidad del País Vasco, Spain.

COTEC (1999) El sistema español de innovación. Diagnóstico y recomendaciones, Fundación COTEC, Madrid, Spain.

Cyert R.M. and Goodman P.S. (1997) Creating effective university-industry alliances: an organizational perspective, Organizational Dynamics, 3, 45-57.

Das T.K. and Teng B. (1998) Between trust and control: developing confidence in partner cooperation in alliances, Academy of Management Review, 23, 491-512.

Dodgson M. (1992) Technological collaboration: problems and pitfalls, Technology Analysis and Strategic Management, 4(1), 83-88.

Edquist C. (2004) Systems of innovation - perspectives and challenges, ch. 7 in Fagerberg J., Mowery D.C. and Nelson R.R. (eds.), Oxford Handbook of Innovation, Oxford University Press, Oxford.

Enright M. (2001) Approaches to market orientation and new product development in smaller enterprises: a proposal for a context rich interpretive framework, Journal of Strategic Marketing, 9(4): 301-313.

European Commission (2001) Building an innovative economy in Europe, Luxembourg.

European Commission (2000) Tendencias en la política europea de innovación y el ambiente para la innovación en la Unión, Documento de trabajo de los servicios de la Comisión, SEC (2000), 1564. 
Faulkner W. and Senker J. (1995) Knowledge frontiers: public sector research and industrial innovation in biotechnology, engineering ceramics, and parallel computing, Oxford University Press, New York.

Fritsch M. and Lukas R. (2001) Who cooperates on R\&D?, Research Policy, 30, 297-312.

Frye J. (1993) University-industry cooperative research yields dividends, International Journal of Technology Management, 8, 577-586.

Fundación Cotec (1999) Relaciones de la empresa con el sistema público de $I+D$, Madrid.

García-Aracil A., Fernández I. and Gutiérrez, A. (2003) Análisis de las actividades de investigación y desarrollo y de cooperación entre las comunidades académica y empresarial de la Comunidad Valencia, Revista Valenciana d'Estudis Autonòmics, 38, 39104.

Geisler E. (1995) Industry-university technology cooperation: a theory of inter-organizational relationships, technology analysis, Technology Analysis and Strategic Management, 7, 217-229.

Generalitat Valenciana (2001) Plan Valenciano de Investigación Científica, Desarrollo Tecnológico e Innovación (PVIDI), official document published by Secretaria del PVIDI de la Generalitat Valencia, Valencia, Spain.

Goodwin M. and Johnston R. (1999) Absorptive capacity, Science and Public Policy, 26(2), 83-90.

Gonard T. (1999) The process of change in relationships between public research and industry: two case studies from France, $R \& D$ Management, 29(2), 143-152.

González X., Jaumandreu J. and Pazó C. (1999) Impacto de las subvenciones en las decisiones de I+D, Fundación Empresa Pública, Documento de Trabajo, 9905.

Green W.H. (1997) Econometric Analysis, third edition, Prentice-Hall, New Jersey. 
Griffith R., Redding S. and Van Reenen J. (2003) R\&D and absorptive capacity: theory and empirical evidence, Scandinavian Journal of Economics, 105(1), 99-118.

Hakanson L. (1993) Managing cooperative research and development: partner selection and contract design, $R \& D$ Management, 23(4), 273-285.

Ham R.M. and Mowery D.C. (1998) Improving the effectiveness of public-private R\&D collaboration: case studies at a US weapons laboratory, Research Policy, 26, 661-675.

Hamel G. and Prahalad C.K. (1994) Competing for the Future, Harvard Business School Press, Boston.

Hameri A.P. (1996) Technology transfer between basic research and industry", Technovation, $16(2), 51-57$.

Hicks D. (2000) Using innovation indicators for assessing the efficiency of industry-science relationships, in Proceedings of the presentation of the paper at the joint German-OECD conference, Berlin.

INE (2002) Estadística sobre las actividades en investigación científica y desarrollo tecnológico (I+D), Madrid.

Ingham M. and Mothe C. (1998) How to learn in R\&D partnerships?, R\&D Management, 28(4), 249-261.

Isaksen A. (2002) Cities and the new economy. The clustering of the software industry in Oslo. Paper to IX National Meeting in ERA, Lisbon.

Isaksen A. and Hauge E. (2002) Regional Clusters in Europe, Observatory of European SMEs, nº 3, European Commission, Luxemburgo.

Jaffe A., Trajtenberg M. and Henderson R. (1993) Geographic localization of knowledge spillovers as evidence by patent citations, Quaterly Journal of Economics, 108, 577-598.

Keeble D. (1997) Small firms, innovation and regional development in Britain in the 1990s, Regional Studies, 31(3), 281-293. 
Kitson M., Martin R. and Tyler P. (2004) Regional competitiveness: An elusive yet key concept?, Regional Studies, 38(9), 991-999.

Kleinknecht A. and Reijnen J.O.N. (1992) Why do firms cooperate on R\&D? An empirical study, Research Policy, 21, 347-360.

Klofsten M., Dylan J.E. and Schärberg, C. (1999) Growing the Linköping Technopole - a longitudinal study of the triple helix development in Sweden, Journal of Technology Transfer, 24(2/3), 125-138.

Lee Y.S. (2000) The sustainability of university-industry research collaboration: an empirical assessment, Journal of Technology Transfer, 25, 111-133.

Lee Y.S. (1996) Technology transfer and the research university: a search for the boundaries of university-industry collaboration, Research Policy, 25, 843-863.

Leydesdorff L. and Etzkowitz H. (2001) The transformation of university-industrygovernment relations, Electronic Journal of Sociology, 5(4).

Lim K. (2000) The many faces of absorptive capacity: spillovers of copper interconnect technology for semiconductor chips, Mimeo, MIT.

Lucking B. (2004) International comparisons of the third community innovation survey (CIS3), Department of Trade and Industry, London.

Lundvall B.A. (1988) Innovation as an interactive process: from user-producer interaction to the national system of innovation, in Dosi et al. (eds), Technical Change and Economic Theory, London: Pinter.

Malmberg A. and Maskell P. (2002) The elusive concept of localization economies: towards a knowledge-based theory of spatial clustering, Environment and Planning A, 34, 429-449.

Maskell P. and Malmberg A. (1999) Localized learning and industrial competitiveness, Cambridge Journal of Economics, 23, 167-185.

Mansfield E. (1991) Academic research and industrial innovation, Research Policy, 20, 1-12. 
Mansfield E. and Lee J.Y. (1996) The modern university: contributor to industrial innovation and recipient of industrial R\&D support, Research Policy, 25, 1047-1058.

McAllister D.J. (1995) Affect and cognition based trust as foundations for interpersonal cooperation in organisations, Academy of Management Journal, 38, 24-59.

Mora E.M. (1999) La cooperación universidad-empresa: un análisis de las dimensiones y tipología de los acuerdos de colaboración, Revista de Ciencias Sociales y Jurídicas Studia Carande, 2(4), 267-286.

NSB, National Science Board (2000) Science and Engineering Indicators. National Science Foundation. US Government Printing Office, Washington, DC.

Nelson R. and Winter S. (1982) An Evolutionary Theory of Economic Change, Harvard University Press, Cambridge, M.A.

OECD (2004) Main Science and Technology Indicators: Research and Development Statistics, OECD, Paris.

OECD (2001) Cities and Learning Regions, Paris: OECD.

OECD (2001a) Managing University/Industry Relationship: The Role of Knowledge Management, OECD, Paris.

OECD (2000) Analytical Report on High Tech Spin-offs, DSTI/STP/TIP, OECD, Paris.

OECD (1998) University Research in Transition, OECD, Paris.

OECD (1997) National Innovation Systems, OECD, Paris.

Okubo Y. and Sjoberg C. (2000) The changing pattern of industrial scientific research collaboration in Sweden, Research Policy, 29(1), 81-98.

Oliver A.L. and Liebeskind J.P. (1998) Three levels of networking for sourcing intellectual capital in biotechnology: implication for studying interorganizational networks, international studies of management, International Studies of Management and Organization, 27(4), 76-103. 
Pagano P. and Schivardi F. (2003) Firm size distribution and growth, Scandinavian Journal of Economics, 105(2), 255-274.

Patel P. and Pavitt K. (1998) National systems of innovation under strain: the internationalisation of corporate R\&D, Electronic Working Paper, SPRU.

Pavitt K. (1984) Sectoral patterns of technical change: towards a taxonomy and a theory, Research Policy, 13(6), 343-373.

Pisano G. (1990) The R\&D boundaries of the firm: an empirical analysis, Administrative Science Quartely, 35, 153-176.

Prahalad C.K. (1998) Managing discontinuities: the emerging challenges, Research Technology Management, 14-22.

Polenske K.R. (2004) Competition, collaboration and cooperation: An uneasy triangle in networks of firms and regions, Regional Studies, 38(9), 1029-1043.

Rea D., Brooks H., Burger R. and LaScala, R. (1997) The semiconductor industry-model for industry university government cooperation, Research Technology Management, 46-54.

Reams R. (1986) University-Industry Research Partnerships. Quorum Books, Westport, Conn.

Roessner D., Lee Y., Shapira P. and Bozeman B. (1996) Evaluation of Iowa State University's Center for Advanced Technology Development, unplublished paper, School of Public Policy, Georgia Institute of Technology.

Rosner M. (1968) Economic determinants of organizational innovation, Administrative Science Quarterly, 12, 614-625.

Santangelo G.D. (2002) The regional geography of corporate patenting in information and communications technology (ICT): Domestic and foreign dimensions, Regional Studies, $36(5), 495-514$. 
Santoro M.D. and Chakrabarti A.K. (1999) Building industry-university research centers: some strategic considerations, International Journal of Management Reviews, 1(3), 225244.

Saviotti P. (1998) On the dynamics of appropriability of tacit and codified knowledge, Research Policy, 26, 834-5-856.

Schartinger D., Rammer C., Fischer M.M. and Fröhlich J. (2002) Knowledge interactions between university and industry in Austria: sectoral patterns and determinants, Research Policy, 31, 303-328.

Schartinger D., Schibany A. and Gassler H. (2001) Interactive relations between university and firms: empirical evidence for Austria, Journal of Technology Transfer, 26, 255-268.

Scott W.R. (1995) Institutions and Organizations. Sage, Thousand Oaks CA.

Seaton R.A.F. and Cordey-Hayes M. (1993) The development and application of interactive models of industrial technology transfer, Technovation, 13(1), 45-53.

Shane S. and Stuart T. (2000) Organizational endowments and the performance of university start-ups, Mimeo, University of Maryland.

Steele L. (1989) Managing Technology. McGraw-Hill, New York.

Teece D.J., Pisano G. and Shuen A. (1997) Dynamic capabilities and strategic management, Strategic Management Journal, 18, 509-533.

Torre A. and Rallet A. (2005) Proximity and localization, Regional Studies, 39(1), 47-59.

Van Rossum W. and Cabo P. (1995) The contribution of research institutes in EUREKA projects, International Journal of Technology Management, 10, 853-866.

Varga A. (2000) Regional economic effects of university research: a survey, Working Paper, Department for Economic Geography and Geoinformatics, University of Economics and Business Administration, Vienna. 
Varga A. (1998) University Research and Regional Innovation, a Spatial Econometric Analysis of Academic Technology Transfers, Kluwer Academic Publishers, London.

Wolfe D. (2003) Knowledge, clusters and learning regions, in Holbrook and Wolfe D. (eds.), Kingstson: School of Policy Studies, Queen's University.

Ziedmonis A.A. (1999) Inward technology transfer by firms: the case of university technology licenses, Mimeo, University of California, Berkeley.

Zmud R.W. (1982) Diffusion of modern software practices: influence of centralization and formalization, Management Science, 28, 1421-1431.

Zucker L.G., Darby M.R. and Armstrong J.S. (2000) University science, venture capital, and the performance of U.S. biotechnology firms, Mimeo, University of California, Los Angeles. 


\section{Tables}

Table 1. Distribution of Valencian firms by activity sector, 2001.

\begin{tabular}{lc}
\hline \multicolumn{1}{c}{ Activity sectors } & \% Distribution \\
\hline Supplier-dominated firms & 51.6 \\
Large-scale firms & 15.0 \\
Specialist suppliers & 21.7 \\
Science-based firms & 9.3 \\
Information-intensive firms & 2.4 \\
Total & 100.0 \\
\hline
\end{tabular}


Table 2. Distribution of Valencian firms by size, 2001.

\begin{tabular}{lc}
\hline \multicolumn{1}{c}{ Firm Size } & \% Distribution \\
\hline Micro (<11 employees) & 8.4 \\
Small (11 to 50 employees) & 70.4 \\
Medium (51 to 250 employees) & 18.0 \\
Large (>250 employees) & 3.1 \\
Total & 100.0 \\
\hline
\end{tabular}

13

14

15

16

17

19

20

21

24

25

26

28

29

30

31

33

34

35

36

37

38

39

40

41

42

44

45

46

47

48

49

51

52

53

54

55

56 
Table 3. Percentage of firms engaged in innovation activities by activity sector, 2001.

\begin{tabular}{lcc}
\hline \multicolumn{1}{c}{ Activity Sector } & Region of Valencia & Spain \\
\hline Supplier-dominated firms & 24.1 & 31.4 \\
Textile, dressing and dyeing of fur & 30.6 & 25.2 \\
Leather and footwear & 20.7 & 26.5 \\
Wood, paper, publishing and printing & 18.4 & 35.6 \\
Furniture & 23.9 & 35.3 \\
Other manufacturing industries & 38.9 & 35.4 \\
\hline Large-scale firms & 38.1 & 33.7 \\
Food products, beverages and tobacco & 27.1 & 34.2 \\
Other non-metallic mineral products (ceramic sector) & 47.4 & 32.8 \\
\hline Specialist suppliers & 21.7 & 37.7 \\
Primary metals and fabricated metal products & 27.8 & 30.2 \\
Machinery and equipment n.e.c. & 10.0 & 46.6 \\
Transport equipment & 38.5 & 39.2 \\
\hline Science-based firms & 63.1 & 47.8 \\
Coke, petroleum, chemical products and man-made fibres & 63.1 & 47.8 \\
\hline Information-intensive firms & 35.3 & 47.1 \\
Telecommunications & 35.3 & 47.1 \\
\hline Total & 29.6 & 35.3 \\
\hline
\end{tabular}


Table 4. Percentage of Valencian firms who reported collaboration with universities, 2001.

\begin{tabular}{lccc}
\multicolumn{1}{c}{ Activity Sector \& Size } & \% Collaboration & \% Perform R\&D & $\begin{array}{c}\text { \% Collaboration } \\
\text { in R\&D activities }\end{array}$ \\
\hline Supplier-dominated firms & 6.4 & 17.2 & 3.3 \\
Large-scale firms & 23.8 & 32.4 & 14.3 \\
Specialist suppliers & 5.9 & 17.1 & 3.9 \\
Science-based firms & 24.6 & 47.7 & 15.4 \\
Information-intensive firms & 23.5 & 35.3 & 17.6 \\
& & & \\
Micro (<11 employees) & 0.0 & 3.4 & 0.0 \\
Small (11 to 50 employees) & 6.5 & 18.5 & 3.4 \\
Medium (51 to 250 employees) & 27.8 & 41.3 & 15.9 \\
Large (>250 employees) & 45.5 & 63.6 & 40.9 \\
& & & \\
Total & 11.0 & 22.7 & 6.6 \\
\hline
\end{tabular}


Table 5. Motives for industry-university collaboration

\begin{tabular}{lc}
\hline & Average score (scale 0-3) \\
\hline Perform joint R\&D & 1.9 \\
Obtain innovative ideas & 2.3 \\
Discern technology trend & 2.2 \\
Staff training & 2.3 \\
Change of technology management & 2.1 \\
Register product innovations & 2.0 \\
Register process innovations & 2.0 \\
\hline
\end{tabular}


Table 6. Average managers' level of education (scale 1 to 5)

\begin{tabular}{llllll}
\hline \multicolumn{1}{r}{ Activity Sector \& Size } & \multicolumn{2}{c}{ Engage in I-U collaboration } & & \multicolumn{2}{c}{ Perform R\&D activities } \\
\cline { 2 - 3 } \cline { 5 - 6 } & Yes & No & & Yes & No \\
\hline Supplier-dominated firms & 4.0 & 3.3 & 3.7 & 3.2 \\
Large-scale firms & 4.3 & 3.6 & 3.9 & 3.6 \\
Specialist suppliers & 4.8 & 3.4 & 4.2 & 3.4 \\
Science-based firms & 4.4 & 4.0 & 4.0 & 4.3 \\
Information-intensive firms & 4.8 & 3.7 & 4.8 & 3.5 \\
& & & & \\
Micro (<11 employees) & n.a. & 3.0 & & n.a. & 3.0 \\
Small (11 to 50 employees) & 4.0 & 3.3 & 3.8 & 3.3 \\
Medium (51 to 250 employees) & 4.6 & 4.0 & 4.3 & 4.1 \\
Large (>250 employees) & 4.5 & 4.1 & & 4.4 & 4.0 \\
& & & & \\
Total & 4.3 & 3.4 & 4.0 & 3.4 \\
\hline
\end{tabular}


Table 7. Factors hindering firms' collaboration with university

\begin{tabular}{lc}
\hline & Average score (scale 0-3) \\
\hline Lack of interest for university research & 1.45 \\
Lack of appropriate collaboration results & 1.51 \\
Lack of qualified personnel from university & 1.71 \\
Obtaining results very slowly & 1.58 \\
Regulations and standards & 1.54 \\
Lack of firms' capacity to absorb university research results & 1.50 \\
Lack of funds for these relationships & 1.78 \\
Uncertainty in results (risk) & 1.56 \\
\hline
\end{tabular}


Table 8. Probit model of industry-university collaboration (z-values in parentheses $)^{\mathrm{a}}$

\begin{tabular}{|c|c|c|c|c|}
\hline Variables & Model I & Model II & Model III & Model IV \\
\hline Chief manager's higher education & $\begin{array}{l}0.606 \\
(3.180) * * *\end{array}$ & $\begin{array}{l}0.522 \\
(2.601)^{* *}\end{array}$ & $\begin{array}{l}0.482 \\
(2.364) * * *\end{array}$ & $\begin{array}{l}0.469 \\
(1.819)^{*}\end{array}$ \\
\hline Product manager's higher education & $\begin{array}{l}0.839 \\
(3.113) * * *\end{array}$ & $\begin{array}{l}0.778 \\
(2.717) * * *\end{array}$ & $\begin{array}{l}0.725 \\
(2.490) * * *\end{array}$ & $\begin{array}{l}0.823 \\
(2.371)^{* * *}\end{array}$ \\
\hline $\mathrm{R} \& \mathrm{D}$ manager's higher education & $\begin{array}{l}1.078 \\
(2.924)^{* * *}\end{array}$ & $\begin{array}{l}0.801 \\
(1.967)^{* *}\end{array}$ & $\begin{array}{l}0.749 \\
(1.812)^{*}\end{array}$ & $\begin{array}{l}1.048 \\
(2.232)^{* * *}\end{array}$ \\
\hline Administrative manager's higher education & $\begin{array}{l}0.547 \\
(3.127) * * *\end{array}$ & $\begin{array}{l}0.456 \\
(2.438) * * *\end{array}$ & $\begin{array}{l}0.456 \\
(2.402) * * *\end{array}$ & $\begin{array}{l}0.474 \\
(2.110)^{* *}\end{array}$ \\
\hline Other chief executives & $\begin{array}{l}1.212 \\
(5.368)^{* * *}\end{array}$ & $\begin{array}{l}1.025 \\
(4.362) * * *\end{array}$ & $\begin{array}{l}1.022 \\
(4.194) * * *\end{array}$ & $\begin{array}{l}1.099 \\
(3.667)^{* * *}\end{array}$ \\
\hline $\begin{array}{l}\text { Large-scale firms (ref. supplier-dominated } \\
\text { firms) }\end{array}$ & & $\begin{array}{l}0.722 \\
(4.073) * * *\end{array}$ & $\begin{array}{l}0.716 \\
(3.957) * * *\end{array}$ & $\begin{array}{l}0.778 \\
(3.571)^{* * *}\end{array}$ \\
\hline Specialist suppliers & & $\begin{array}{l}-0.024 \\
(-0.116)\end{array}$ & $\begin{array}{l}0.016 \\
(0.078)\end{array}$ & $\begin{array}{l}0.092 \\
(0.364)\end{array}$ \\
\hline Science-based firms & & $\begin{array}{l}0.708 \\
(3.433) * * *\end{array}$ & $\begin{array}{l}0.719 \\
(3.400) * * *\end{array}$ & $\begin{array}{l}1.126 \\
(4.307)^{* * *}\end{array}$ \\
\hline Information-intensive firms & & $\begin{array}{l}0.799 \\
(2.154) * *\end{array}$ & $\begin{array}{l}0.772 \\
(2.018)^{* *}\end{array}$ & $\begin{array}{l}0.786 \\
(1.980) * *\end{array}$ \\
\hline Medium and large size (ref. micro \& small) & & $\begin{array}{l}0.284 \\
(1.940) *\end{array}$ & $\begin{array}{l}0.250 \\
(1.679) *\end{array}$ & $\begin{array}{l}0.167 \\
(0.947)\end{array}$ \\
\hline Perform joint R\&D & & & $\begin{array}{l}0.212 \\
(2.315) * *\end{array}$ & $\begin{array}{l}0.316 \\
(2.719) * * *\end{array}$ \\
\hline Obtain innovative ideas & & & $\begin{array}{l}-0.035 \\
(-0.294)\end{array}$ & $\begin{array}{l}-0.022 \\
(-0.147)\end{array}$ \\
\hline Discern technology trend & & & $\begin{array}{l}0.098 \\
(0.896)\end{array}$ & $\begin{array}{l}0.144 \\
(1.051)\end{array}$ \\
\hline Staff training & & & $\begin{array}{l}-0.115 \\
(-1.165)\end{array}$ & $\begin{array}{l}-0.099 \\
(-0.782)\end{array}$ \\
\hline Change of technology management & & & $\begin{array}{l}-0.071 \\
(-0.624)\end{array}$ & $\begin{array}{l}-0.022 \\
(-0.158)\end{array}$ \\
\hline Register product innovations & & & $\begin{array}{l}0.045 \\
(0.324)\end{array}$ & $\begin{array}{l}-0.046 \\
(-0.262)\end{array}$ \\
\hline Register process innovations & & & $\begin{array}{l}-0.016 \\
(-0.114)\end{array}$ & $\begin{array}{l}-0.016 \\
(-0.092)\end{array}$ \\
\hline Lack of interest for university research & & & & $\begin{array}{l}0.100 \\
(1.027)\end{array}$ \\
\hline Lack of appropriate collaboration results & & & & $\begin{array}{l}0.001 \\
(0.006)\end{array}$ \\
\hline Lack of qualified personnel from university & & & & $\begin{array}{l}-0.028 \\
(-0.254)\end{array}$ \\
\hline Obtaining results very slowly & & & & $\begin{array}{l}-0.217 \\
(-1.975) * *\end{array}$ \\
\hline Regulations and standards & & & & $\begin{array}{l}-0.038 \\
(-0.387)\end{array}$ \\
\hline $\begin{array}{l}\text { Lack of firms' capacity to absorb } \\
\text { university research results }\end{array}$ & & & & $\begin{array}{l}-0.093 \\
(-0.8681)\end{array}$ \\
\hline Lack of funds for these relationships & & & & $\begin{array}{l}-0.099 \\
(-0.965)\end{array}$ \\
\hline Uncertainty in results (risk) & & & & $\begin{array}{l}0.137 \\
(1.248)\end{array}$ \\
\hline Intercept & $\begin{array}{l}-1.701 \\
(-13.750)\end{array}$ & $\begin{array}{l}-2.065 \\
(-12.244)\end{array}$ & $\begin{array}{l}-2.252 \\
(-7.733)\end{array}$ & $\begin{array}{l}-2.126 \\
(-5.637)\end{array}$ \\
\hline Observations & 700 & 700 & 700 & 700 \\
\hline $\operatorname{Lr} \chi^{2}(5 ; 10 ; 17 ; 26)$ & 37.85 & 72.31 & 81.37 & 87.39 \\
\hline Log likelihood & -223.634 & -206.404 & -201.874 & -198.864 \\
\hline
\end{tabular}


Table 9. Industry-University interaction activities preferred

\begin{tabular}{lc}
\hline & Percentage \\
\hline Advice and technical support & 76.2 \\
Education of personnel & 69.3 \\
Training students & 66.5 \\
Informal contacts & 60.9 \\
Joint R\&D projects & 58.6 \\
Contract R\&D & 50.2 \\
Develop joint R\&D centres & 43.1 \\
Patenting & 36.8 \\
Personnel mobility & 30.8 \\
\hline
\end{tabular}




\section{Appendix A}

Figure 1A. The Region of Valencia.

1

3

4

5

6

7

8

9

10

11

12

13

14

15

16

17

18

19

20

21

22

23

24

25

26

27

28

29

30

31

32

33

34

35

36

37

38

39

40

41

42

43

44

45

46

47

48

49

50

51

52

53

54

55

56

57

58

59

60 